\title{
Effect of phytosterols on rumen fermentation in vitro
}

\author{
Y.M. Xi, Z.H. Jin, L.J. Lin and Z.Y. Han \\ Institute of Dairy Science, College of Animal Science and Technology, \\ Nanjing Agricultural University, Weigang, Nanjing, China \\ Corresponding author: Z.Y. Han \\ E-mail: zyhan6708@njau.edu.cn \\ Genet. Mol. Res. 13 (2): 3869-3875 (2014) \\ Received September 16, 2013 \\ Accepted December 17, 2013 \\ Published May 16, 2014 \\ DOI http://dx.doi.org/10.4238/2014.May.16.12
}

\begin{abstract}
We investigated the effect of phytosterols on rumen fermentation in vitro using gas syringes as incubators. Phytosterols were dissolved in ethyl acetate $(8.3 \%)$ and added at various concentrations to the common diet in rumen fluid. In vitro gas production (GP) was recorded after $3,6,12,18$, and $24 \mathrm{~h}$ incubation. Incubation was stopped at 6,12 , and $24 \mathrm{~h}$ and the inoculants were then tested for $\mathrm{pH}$, dry matter digestibility (DMD), microbial protein yield (MCP), lactic acid, NH3-N, and volatile fatty acids (VFAs). GP was consistently higher than the control; particularly, treatments at 12,18 , and $24 \mathrm{~h}$ reached extremely significant levels $(\mathrm{P}<0.01)$. Compared to the control group, the $\mathrm{pH}$ of ruminal fluid was slightly lower after incubation, and DMD and MCP increased with increasing phytosterol level except for the content of MCP at $6 \mathrm{~h}$, which changed only minimally. Lactate was significantly lower after treatment compared to the control at $12 \mathrm{~h}(\mathrm{P}<0.01)$ and $24 \mathrm{~h}(\mathrm{P}<0.05)$, while $\mathrm{NH}_{3}-\mathrm{N}$ at $12 \mathrm{~h}(\mathrm{P}<0.05)$ and $24 \mathrm{~h}(\mathrm{P}<0.01)$ after treatment decreased significantly. Acetate, propionate, butyrate, and total VFA for all treatments were higher than those of the control, particularly for butyrate at $6 \mathrm{~h}(\mathrm{P}<0.01)$. These results suggest that phytosterols modify rumen fermentation by inhibiting released harmful products and promoting the release of beneficial product, which may be
\end{abstract}


useful for improving nutrient utilization and animal health.

Key words: Phytosterols; Rumen fermentation; Cow

\section{INTRODUCTION}

Phytosterols, also known as plant sterols, belong to the triterpene family, which includes more than 200 different sterols among the more than 4000 types of triterpenes. These compounds cannot be synthesized by animals or humans, but are naturally present in vegetable products, principally oils, pulses, and dried fruits (Goad et al., 1991). Phytosterols play an important role in reducing blood cholesterol levels, controlling certain illnesses such as cancers of the colon, breast, and prostate (Awad and Fink, 2000), and preventing prostatic hyperplasia (Wilt et al., 1999). Their function as immune modulators and their anti-inflammatory properties have been described previously (Bouic, 2001). Several studies have also shown that these compounds can be used as antioxidants for plants or animals (Lampi et al., 1999). Recently, products enriched in phytosterols have become commonly used in North America, Europe, and Asia. Phytosterols, phytostanols, and phytosterol esters have been considered generally recognized as safe (GRAS) for a range of food applications by the U.S. Food and Drug Administration, and were approved as new feed additives by the Ministry of Agriculture of China in 2008. However, few studies have examined the use of phytosterols as a feed additive for ruminants because the complicated rumen is considerably different from the system of mono-gastric animals. We found that oral supplementation of plant sterols could improve milk yield by $0.44-1.71 \mathrm{~kg} /$ day and could decrease ketone and milk urea nitrogen (MUN) contents in the milk (Jin, 2010). The objective of the present study was to evaluate the effect of phytosterols on rumen fermentation in vitro and to understand the mechanism by which phytosterols improve dairy cow performance.

\section{MATERIAL AND METHODS}

\section{Materials}

The substrate used was a common total mixed ration diet (with a 5:5 forage:concentrate diet, $54.6 \%$ dry matter, $17.15 \%$ crude protein, and $34.72 \%$ neutral detergent fiber), which was dried at $65^{\circ} \mathrm{C}$ for $48 \mathrm{~h}$ and broken up by passing it through a $1-\mathrm{mm}$ screen. Phytosterols at $91 \%$ purity (including $40.95 \% \beta$-sitosterol, $24.57 \%$ campesterol, $21.84 \%$ stigmasterol, and $3.64 \%$ brassicasterol) were obtained from Jiangsu Chunzhigu Development Co., Ltd. (Jiangsu, China). Phytosterols appeared as white powder and were insoluble in water, but dissolved in some organic solvents.

\section{Experimental design}

According to Menke and Steingass (1988), 100-mL glass syringes were used as incubators. Four groups (control, treatment I, treatment II, and treatment III) dissolved in $6 \mathrm{~mL}$ $8.3 \%$ ethyl acetate with phytosterols at $0,1,3$, and $6 \mu \mathrm{g}$, respectively, were incubated with 200 $\mathrm{mg}$ TMR (total mixed ration). Syringes were filled with $30 \mathrm{~mL}$ medium consisting of $10 \mathrm{~mL}$ 
rumen fluid and $20 \mathrm{~mL}$ buffer solution as described by Menke and Steingass (1988). Rumen fluid was collected from 3 healthy dairy cows, which were killed after a 7-day adaptation to the diet. The syringes were placed in a water bath at $39^{\circ} \mathrm{C}$. A total of 48 syringes were incubated. In vitro gas production (GP) was recorded at 3, 6, 12, 18, and $24 \mathrm{~h}$ incubation. Four syringes from each group were stopped at 6,12 , and $24 \mathrm{~h}$ after inoculation. The medium was discharged into a $50-\mathrm{mL}$ weighted centrifuge tube and then immersed in ice water to stop fermentation. After measuring $\mathrm{pH}$, the tubes were centrifuged at $150 \mathrm{~g}$ for $15 \mathrm{~min}$ to separate the deposits and supernatant for the determination of dry matter digestibility (DMD), microbial protein yield (MCP), lactic acid, NH3-N, and volatile fatty acids (VFAs).

\section{Measurement of in vitro fermentation parameters}

The $\mathrm{pH}$ of the rumen liquor was determined immediately after removal using a $\mathrm{pH}$ meter (model pH211; Hanna; Smithfield, RI, USA). For determining the in vitro digestibility of dry matter, tubes were centrifuged at $150 \mathrm{~g}$ for $15 \mathrm{~min}$ and the residues were washed twice with distilled water, centrifuged again, and dried to a constant weight at $65^{\circ} \mathrm{C}$. The index was calculated based on dispersion. NH3-N concentration was determined by colorimetry (Searle, 1984). Concentrations of MCP were determined based on Lowry et al. (1951), with modifications described in Makkar et al. (1982), and bovine serum albumin was used as a standard. Lactic acid was determined using the method described by Barker and Summerson (1941), and calcium lactate was used as a standard. To determine VFAs, $1 \mathrm{~mL}$ fermentation medium was placed in centrifuge tubes, mixed uniformly with $0.2 \mathrm{~mL} 25 \%$ metaphosphoric acid using crotonic acid as an internal standard, and then centrifuged at 12,000 $\mathrm{g}$ for $10 \mathrm{~min}$. The supernatant was decanted into another test tube, capped, and stored in a refrigerator at $4^{\circ} \mathrm{C}$ until analysis by gas chromatography (GC-14B; Shimadzu). Subsamples were injected into a $30 \mathrm{~m}$ x $0.32 \mathrm{~mm} \times 0.25 \mu \mathrm{m}$ capillary. The temperatures of the detector, column, and vaporization were $220^{\circ}, 130^{\circ}$, and $180^{\circ} \mathrm{C}$, respectively. Nitrogen was used as a carrier.

\section{Statistical analysis}

The effect of different concentrations of plant sterols on the various parameters was evaluated by using the one-way analysis of variance (ANOVA) protocol in SPSS13.0 version 13.0, 2004 (SPSS, Inc.; Chicago, IL, USA). One-way ANOVA was again used to determine whether the differences were significant. This was followed by multiple comparisons testing using least significant difference (LSD) to identify differences. Means were compared by employing the LSD multiple range test at a significance level of $\mathrm{P}<0.05$. All data are reported as means \pm standard error (SE).

\section{RESULTS}

GP was consistently higher than the control at $41.13,39.83$, and $44.5 \mathrm{~mL}$ at $24 \mathrm{~h}$, for treatments I, II, and III, respectively (Table 1). GP for treatment III was significantly higher than that of the control, except at $6 \mathrm{~h}(\mathrm{P}<0.01$ and $\mathrm{P}<0.05$ at $3 \mathrm{~h})$. GP for treatment II at $12 \mathrm{~h}$ and treatment $\mathrm{I}$ at $18 \mathrm{~h}$ and $24 \mathrm{~h}$ were also significantly higher than that of the control $(\mathrm{P}<0.05)$. 
Table 1. Influence of phytosterols on in vitro gas production.

\begin{tabular}{|c|c|c|c|c|}
\hline Time & Control $(\mathrm{mL})$ & Treatment I (mL) & Treatment II $(\mathrm{mL})$ & Treatment III (mL) \\
\hline $3 \mathrm{~h}$ & $2.77 \pm 0.21^{\mathrm{a}}$ & $3.00 \pm 0.27^{\mathrm{ab}}$ & $3.15 \pm 0.25^{\mathrm{ab}}$ & $3.72 \pm 0.35^{b}$ \\
\hline $6 \mathrm{~h}$ & $10.54 \pm 0.39^{\mathrm{a}}$ & $10.95 \pm 0.51^{\mathrm{a}}$ & $11.20 \pm 0.66^{\mathrm{a}}$ & $11.67 \pm 0.26^{\mathrm{a}}$ \\
\hline $12 \mathrm{~h}$ & $22.25 \pm 0.56^{\mathrm{Aa}}$ & $23.08 \pm 0.71^{\mathrm{ABab}}$ & $24.08 \pm 0.70^{\mathrm{ABbc}}$ & $25.43 \pm 0.37^{\mathrm{Bc}}$ \\
\hline $18 \mathrm{~h}$ & $30.86 \pm 1.07^{\mathrm{Aa}}$ & $34.50 \pm 0.54^{\mathrm{ABbc}}$ & $33.00 \pm 0.89^{\mathrm{ABab}}$ & $36.13 \pm 0.77^{\mathrm{Bc}}$ \\
\hline $24 \mathrm{~h}$ & $37.37 \pm 1.34^{\mathrm{Aa}}$ & $41.13 \pm 0.43^{\mathrm{ABb}}$ & $39.83 \pm 0.96^{\mathrm{ABab}}$ & $44.50 \pm 0.61^{\mathrm{Bc}}$ \\
\hline
\end{tabular}

Within the same row different lowercase letters mean significant at $\mathrm{P}<0.05$ and different capital letters mean significant at $\mathrm{P}<0.01$.

The rumen fermentation parameters are shown in Tables 2 and 3. The presence of phytosterols decreased $\mathrm{pH}$, lactate, and $\mathrm{NH}_{3}-\mathrm{N}$ levels, but increased $\mathrm{DMD}, \mathrm{MCP}$, and VFA levels. The $\mathrm{pH}$ of treatment III was significantly lower than that of the control at $24 \mathrm{~h}(\mathrm{P}<$ 0.05 ), but all values were within a normal range (from 5.5-6.8). Lactate from treatment III was significantly lower than the control at $12 \mathrm{~h}(\mathrm{P}<0.01)$ and $24 \mathrm{~h}(\mathrm{P}<0.05) . \mathrm{NH}_{3}-\mathrm{N}$ from treatment III at $12 \mathrm{~h}(\mathrm{P}<0.05)$ and $24 \mathrm{~h}(\mathrm{P}<0.01)$, and from treatment II at $24 \mathrm{~h}(\mathrm{P}<0.05)$ was significantly lower than that of the control. DMD was significantly higher than the control at $24 \mathrm{~h}(\mathrm{P}<0.01)$, except that DMD for treatment III over all times measured and for treatment II at $6 \mathrm{~h}$ was significantly higher than the control $(\mathrm{P}<0.01)$. MCP content was higher than the control except for treatment I at $6 \mathrm{~h}$, which was slightly lower than the control, and treatment III, which was significantly higher than the control at $24 \mathrm{~h}(\mathrm{P}<0.01)$.

Table 2. Influence of phytosterols on rumen fermentation parameters.

\begin{tabular}{lccccc}
\hline Item & Time $(\mathrm{h})$ & Control & Treatment I & Treatment II & Treatment III \\
\hline $\mathrm{pH}$ & 6 & $6.87 \pm 0.03^{\mathrm{a}}$ & $6.85 \pm 0.02^{\mathrm{a}}$ & $6.86 \pm 0.02^{\mathrm{a}}$ & $6.83 \pm 0.03^{\mathrm{a}}$ \\
& 12 & $6.84 \pm 0.01^{\mathrm{a}}$ & $6.80 \pm 0.01^{\mathrm{a}}$ & $6.82 \pm 0.01^{\mathrm{a}}$ & $6.83 \pm 0.02^{\mathrm{a}}$ \\
$\mathrm{DMD}(\%)$ & 24 & $6.77 \pm 0.01^{\mathrm{a}}$ & $6.74 \pm 0.01^{\mathrm{ab}}$ & $6.75 \pm 0.01^{\mathrm{ab}}$ & $6.73 \pm 0.01^{\mathrm{b}}$ \\
& 6 & $18.19 \pm 2.41^{\mathrm{Aa}}$ & $19.40 \pm 0.82^{\mathrm{Aa}}$ & $23.84 \pm 0.89^{\mathrm{Bb}}$ & $24.41 \pm 0.32^{\mathrm{Bb}}$ \\
& 12 & $25.83 \pm 0.49^{\mathrm{Aa}}$ & $8.10 \pm 0.17^{\mathrm{ab}}$ & $27.23 \pm 0.68^{\mathrm{a}}$ & $30.02 \pm 1.33^{\mathrm{Bb}}$ \\
$\mathrm{MCP}(\mathrm{mg} / \mathrm{dL})$ & 24 & $34.08 \pm 21.64^{\mathrm{Aa}}$ & $37.45 \pm 0.37^{\mathrm{ABb}}$ & $41.60 \pm 1.24^{\mathrm{BCc}}$ & $45.62 \pm 0.51^{\mathrm{Cd}}$ \\
& 6 & $11.34 \pm 0.44^{\mathrm{a}}$ & $11.18 \pm 0.47^{\mathrm{a}}$ & $11.55 \pm 0.73^{\mathrm{a}}$ & $11.47 \pm 0.14^{\mathrm{a}}$ \\
& 12 & $13.91 \pm 0.34^{\mathrm{a}}$ & $13.86 \pm 0.33^{\mathrm{a}}$ & $14.10 \pm 0.51^{\mathrm{a}}$ & $14.31 \pm 0.25^{\mathrm{a}}$ \\
Lactate (mM) & 24 & $13.97 \pm 0.14^{\mathrm{Aa}}$ & $1.01 \pm 0.49^{\mathrm{Aa}}$ & $14.77 \pm 0.43^{\mathrm{ABa}}$ & $16.19 \pm 0.35^{\mathrm{Bb}}$ \\
& 6 & $1.34 \pm 0.10^{\mathrm{a}}$ & $1.34 \pm 0.07^{\mathrm{a}}$ & $1.28 \pm 0.19^{\mathrm{a}}$ & $0.98 \pm 0.09^{\mathrm{a}}$ \\
& 12 & $1.63 \pm 0.06^{\mathrm{Aa}}$ & $1.47 \pm 0.10^{\mathrm{ABa}}$ & $1.32 \pm 0.17^{\mathrm{ABab}}$ & $1.00 \pm 0.08^{\mathrm{Bb}}$ \\
$\mathrm{NH}{ }_{3} \mathrm{~N}(\mathrm{mg} / \mathrm{dL})$ & 24 & $1.39 \pm 0.06^{\mathrm{a}}$ & $1.16 \pm 0.16^{\mathrm{ab}}$ & $1.13 \pm 0.15^{\mathrm{ab}}$ & $0.85 \pm 0.05^{\mathrm{b}}$ \\
& 6 & $8.93 \pm 0.15^{\mathrm{a}}$ & $9.00 \pm 0.20^{\mathrm{a}}$ & $8.50 \pm 0.13^{\mathrm{a}}$ & $8.49 \pm 0.25^{\mathrm{a}}$ \\
& 12 & $10.07 \pm 0.26^{\mathrm{a}}$ & $9.16 \pm 0.07^{\mathrm{ab}}$ & $8.57 \pm 0.18^{\mathrm{ab}}$ & $7.65 \pm 0.12^{\mathrm{b}}$ \\
& 24 & $9.88 \pm 0.14^{\mathrm{Aa}}$ & $9.80 \pm 0.29^{\mathrm{Aa}}$ & $8.78 \pm 0.17^{\mathrm{ABb}}$ & $8.10 \pm 0.49^{\mathrm{Bb}}$ \\
\hline
\end{tabular}

$\mathrm{DMD}=$ dry matter digestibility; $\mathrm{MCP}=$ microbial protein yield. Within the same row different lowercase letters mean significant at $\mathrm{P}<0.05$ and different capital letters mean significant at $\mathrm{P}<0.01$.

VFAs were higher in treatments than the control for most times except for $6 \mathrm{~h}$, and for butyrate at $24 \mathrm{~h}$, which was slightly lower than that of control. Acetate and total VFA in all treatments were significantly higher than the control $(\mathrm{P}<0.05)$ at $6 \mathrm{~h}$. The amount of butyrate in all treatments $(\mathrm{P}<0.01)$ and other VFAs in treatment III $(\mathrm{P}<0.05)$ were significantly higher than in the control. The amount of propionate from treatment II $(\mathrm{P}<0.05)$ and treatment III $(\mathrm{P}<0.01)$, butyrate from treatment I $(\mathrm{P}<0.05)$ and treatment III $(\mathrm{P}<0.05)$, and TVFA from treatment II $(\mathrm{P}<0.05)$ and treatment III $(\mathrm{P}<0.05)$ were significantly higher than in the control 
at $12 \mathrm{~h}$. Acetate levels in treatment III $(\mathrm{P}<0.01)$, propionate from treatment II and treatment III $(\mathrm{P}<0.05)$, other VFAs from treatment I and treatment III $(\mathrm{P}<0.05)$, and TVFA from treatment III $(\mathrm{P}<0.05)$ were significantly higher compared to the control at $24 \mathrm{~h}$.

\begin{tabular}{|c|c|c|c|c|c|}
\hline Time & Item & Control & Treatment I & Treatment II & Treatment III \\
\hline \multirow[t]{5}{*}{$\overline{6 \mathrm{~h}}$} & Acetate & $18.01 \pm 2.48^{\mathrm{a}}$ & $24.59 \pm 1.40^{\mathrm{b}}$ & $24.03 \pm 0.58^{\mathrm{b}}$ & $24.20 \pm 1.08^{b}$ \\
\hline & Propionate & $4.61 \pm 0.39^{\mathrm{a}}$ & $4.80 \pm 0.11^{\mathrm{a}}$ & $5.42 \pm 0.31^{\mathrm{a}}$ & $5.16 \pm 0.25^{\mathrm{a}}$ \\
\hline & Butyrate & $1.04 \pm 0.09^{\mathrm{A}}$ & $1.31 \pm 0.02^{\mathrm{B}}$ & $1.33 \pm 0.03^{\mathrm{B}}$ & $1.29 \pm 0.03^{\mathrm{B}}$ \\
\hline & Other VFA ${ }^{1}$ & $0.56 \pm 0.03^{\mathrm{A}}$ & $0.53 \pm 0.01^{\mathrm{A}}$ & $0.61 \pm 0.05^{\mathrm{A}}$ & $0.71 \pm 0.05^{\mathrm{B}}$ \\
\hline & TVFA & $24.21 \pm 2.67^{\mathrm{a}}$ & $31.24 \pm 1.51^{\mathrm{b}}$ & $31.27 \pm 1.20^{\mathrm{b}}$ & $31.48 \pm 0.89^{\mathrm{b}}$ \\
\hline \multirow[t]{5}{*}{$12 \mathrm{~h}$} & Acetate & $28.59 \pm 1.64^{\mathrm{a}}$ & $31.26 \pm 0.89^{\mathrm{a}}$ & $31.40 \pm 0.69^{\mathrm{a}}$ & $31.61 \pm 1.11^{\mathrm{a}}$ \\
\hline & Propionate & $6.34 \pm 0.23^{\mathrm{Aa}}$ & $6.82 \pm 0.28^{\mathrm{ab}}$ & $7.62 \pm 0.38^{\mathrm{bc}}$ & $7.98 \pm 0.35^{\mathrm{BC}}$ \\
\hline & Butyrate & $1.64 \pm 0.06^{\mathrm{a}}$ & $1.90 \pm 0.07^{\mathrm{a}}$ & $1.83 \pm 0.04^{\mathrm{ab}}$ & $1.88 \pm 0.02^{\mathrm{b}}$ \\
\hline & Other VFA & $0.61 \pm 0.05^{\mathrm{a}}$ & $0.74 \pm 0.05^{\mathrm{a}}$ & $0.71 \pm 0.04^{a}$ & $0.74 \pm 0.01^{\mathrm{a}}$ \\
\hline & TVFA & $37.43 \pm 126^{\mathrm{a}}$ & $40.71 \pm 1.21^{\mathrm{ab}}$ & $41.95 \pm 1.08^{\mathrm{b}}$ & $41.60 \pm 0.77^{\mathrm{b}}$ \\
\hline \multirow[t]{5}{*}{$24 \mathrm{~h}$} & Acetate & $41.14 \pm 1.49^{\mathrm{Aa}}$ & $42.43 \pm 0.93^{\mathrm{a}}$ & $43.03 \pm 1.00^{\mathrm{a}}$ & $46.37 \pm 0.40^{\mathrm{Bb}}$ \\
\hline & Propionate & $8.29 \pm 0.19^{\mathrm{a}}$ & $9.08 \pm 0.29^{\mathrm{a}}$ & $9.47 \pm 0.42^{b}$ & $9.36 \pm 0.23^{b}$ \\
\hline & Butyrate & $2.23 \pm 0.05^{\mathrm{a}}$ & $2.24 \pm 0.06^{\mathrm{a}}$ & $2.28 \pm 0.08^{\mathrm{a}}$ & $2.32 \pm 0.02^{\mathrm{a}}$ \\
\hline & Other VFA & $0.91 \pm 0.06^{\mathrm{Aa}}$ & $1.26 \pm 0.08^{\mathrm{Bb}}$ & $1.00 \pm 0.05^{\mathrm{Aa}}$ & $1.26 \pm 0.10^{\mathrm{Bb}}$ \\
\hline & TVFA & $52.56 \pm 1.65^{\mathrm{Aa}}$ & $54.01 \pm 0.81^{\mathrm{ABa}}$ & $55.94 \pm 1.12^{\mathrm{ABab}}$ & $59.05 \pm 0.61^{\mathrm{Bb}}$ \\
\hline
\end{tabular}

Within the same row different lowercase letters mean significant at $\mathrm{P}<0.05$ and different capital letters mean significant at $\mathrm{P}<0.01$. Other VFA1 $=$ the sum of isobutyrate, isovalerate and valerate.

\section{DISCUSSION}

As a new type of feed additive, phytosterols are widely used in animal husbandry to reduce blood cholesterol levels and enhance animal growth. However, few studies have examined the impact of phytosterols on ruminants owing to the complicated rumen. One of the goals of ruminal nutritionists and microbiologists is to improve ruminant nutritional efficiency by manipulating the ruminal microbial ecosystem. The metabolism of phytosterols is generally associated with lipids (Albrecht et al., 2002). In rumen fermentation, many unsaturated fatty acids, such as triglyceride and galactose-esters are hydrolyzed to free fatty acids by microbial lipases. Microbes can also hydrogenate unsaturated fatty acids through the action of isomerase and reductase (Bauchart, 1993). Most phytosterols have 1 or 2 carbon-carbon double bonds, which may be converted to phytostanols by chemical hydrogenation or as conjugated forms in which the $3 \beta-\mathrm{OH}$ group is esterified to a fatty acid or a hydroxycinnamic acid, or glycosylated with a glucose or a 6-fatty-acyl hexose (Moreau et al., 2002). During rumen fermentation, phytosterols can be converted into phytostanols through the reduction of the double bond at position 5, forming a subgroup of "sterols" or phytosterol fatty acid esters (PSEs). However, in vivo studies showed that phytostanols and PSEs may produce a more marked effect. Heinemann et al. (1988) reported that sitotanol at a level of $1.5 \mathrm{~g} /$ day was required to lower serum cholesterol significantly in humans, whereas up to $20 \mathrm{~g}$ /day sitosterol was required to achieve the same effect in humans. Commercial cholesterol-lowering spreads and supplements enriched with sitotanol and sterol esters are recommended at a dose of 300 $\mathrm{mg}$ /day (Hallikainen et al., 2000). These results may explain why a lower level is being used on ruminants. We previously found that dairy cows that received a diet mixed with $200 \mathrm{mg} / \mathrm{day}$ or $800 \mathrm{mg} /$ day of phytosterols showed increased milk production by $1.71 \mathrm{~kg} /$ day and $0.44 \mathrm{~kg} /$ day, respectively (Jin, 2010). Milk ketones and MUN in treated cows were significantly lower 
than in the control. This result indicates that a low level of phytosterols may decrease plasma cholesterol, improve oxidation enzyme activities, and decrease oxidative products in dairy cows compared with high dosages (up to 25-50 g/day) in monogastric animals (Jin, 2010).

$\mathrm{pH}$ is an important parameter that reflects the extent and pattern of diet fermentation. In our study, the $\mathrm{pH}$ of ruminal fluid following the treatments was slightly decreased compared to the control value, which may be due to the increased production of VFAs. However, all values were in the normal range $(\mathrm{pH} 5.5-6.8) . \mathrm{NH}_{3}-\mathrm{N}$ is the degradation product of exogenous protein and is the nitrogen-containing material for MCP synthesis. However, excessive $\mathrm{NH}_{3}-\mathrm{N}$ can increase urea concentration in fluids in the urogenital tract, impairing reproductive performance (Ferguson and Chalupa, 1989). Consumption of excessive CP increases energy requirements by $13.3 \mathrm{kcal}$ of digestible energy $/ \mathrm{g}$ of excessive $\mathrm{N}$, which also has a negative impact on the environment (National Research Council, 1989). In our study, adding a low level of phytosterols decreased $\mathrm{NH}_{3}-\mathrm{N}$, but increased the production of MCP, which may be attributed to a decreased number of protozoa. Jouany (1996) hypothesized that ciliate protozoa contribute significantly to intraruminal cycling of microbial $\mathrm{N}$ and the efficiency of MCP synthesis; thus, a reduced protozoal population may improve dietary $\mathrm{N}$ utilization and increase MCP content in the intestine.

In this study, GP was increased, while lactate was decreased. More efficient lactate removal may help prevent acidosis and indirectly stimulate fiber digestion. Phillipson and McAnally (1942) noted that an increase in fatty acids was associated with a decrease in lactic acid. Improvement in GP may function together with the removal of lactate to buffer ruminal fermentation.

Previous studies have suggested that phytosterols inhibit the activity of some lipases, esterase, and other enzymes involved in the sterol absorption process (Trautwein et al., 2003). We also found that phytosterols could inhibit the activities of lipoproteinesterase, hepatic lipase, and total lipase in the blood (Xi YM, Jin ZH, Lin LJ and Han ZY, unpublished results). Inhibition of any of these enzymes can result in lipid degradation in the rumen, which would have been utilized in the intestine for better dairy performance. Jenkins (1993) reported that lipid degradation might promote a decrease in cellulose degradation. VFAs are the end products of rumen microbial fermentation and represent the main supply of metabolizable energy for ruminants (Van Soest, 1982). Typically, propionate has a higher percentage in non-structural carbohydrate-fermented products, while fermentative fibrous material mainly produces acetic acid. Our study indicated that DMD and the production of VFAs increased quickly, which may be rooted in the improved degradation of cellulose and protein. This indicates that phytosterols can improve rumen metabolism and increase production capacity.

\section{CONCLUSION}

The addition of phytosterols influenced rumen fermentation in vitro, reduced the production of $\mathrm{NH}_{3}-\mathrm{N}$ and lactate concentration, and increased microbial mass yield, in vitro DMD, and VFAs. Further studies are required to understand the mechanism of ruminal fermentation in ruminants.

\section{ACKNOWLEDGMENTS}

We would like to thank the Milk Industry Group Company of Nanjing for providing dairy cows and the common diet for the experiment. Research supported by National Supporting Projects for Science and Techniques (\#2012BAD12B10). 


\section{REFERENCES}

Albrecht C, Elliott JI, Sardini A, Litman T, et al. (2002). Functional analysis of candidate ABC transporter proteins for sitosterol transport. Biochim. Biophys. Acta 1567: 133-142.

Awad AB and Fink CS (2000). Phytosterols as anticancer dietary components: evidence and mechanism of action. J. Nutr. 130: $2127-2130$.

Barker SB and Summerson WH (1941). The colorimetric determination of lactic acid in biological material. J. Biol. Chem. 138: 535-554.

Bauchart D (1993). Lipid absorption and transport in ruminants. J. Dairy Sci. 76: 3864-3881.

Bouic PJ (2001). The role of phytosterols and phytosterolins in immune modulation: a review of the past 10 years. Curr. Opin. Clin. Nutr. Metab. Care 4: 471-475.

Ferguson JD and Chalupa W (1989). Impact of protein nutrition on reproduction in dairy cows. J. Dairy Sci. 72: 746-766. Goad JL, Charlewood BV and Banthorpe DV (1991). Methods in Plant Biochemistry. Academic Press, London.

Hallikainen MA, Sarkkinen ES and Uusitupa MI (2000). Plant stanol esters affect serum cholesterol concentrations of hypercholesterolemic men and women in a dose-dependent manner. J. Nutr. 130: 767-776.

Heinemann T, Pietruck B, Kullak-Ublick G and von Bergmann K (1988). Comparison of sitosterol and sitostanol on inhibition of intestinal cholesterol absorption. Agents Actions Suppl. 26: 117-122.

Jenkins TC (1993). Lipid metabolism in the rumen. J. Dairy Sci. 76: 3851-3863.

Jin ZH (2010). Application of Phytosterols and its Mechanisms in Dairy Cows. Nanjing Agricultural University. Nanjing.

Jouany JP (1996). Effect of rumen protozoa on nitrogen utilization by ruminants. J. Nutr. 126: 1335S-1346S.

Lampi AM, Dimberg LH and Kamal-Eldin A (1999). A study on the influence of fucosterol on thermal polymerisation of purified high oleic sunflower triacylglycerols. J. Sci. Food Agric. 79: 573-579.

Lowry OH, Rosebrough NJ, Farr AL and Randall RJ (1951). Protein measurement with the Folin phenol reagent. J. Biol. Chem. 193: 265-275.

Makkar HP, Sharma OP, Dawra RK and Negi SS (1982). Simple determination of microbial protein in rumen liquor. $J$. Dairy Sci. 65: 2170-2173.

Menke KH and Steingass H (1988). Estimation of the energetic feed value obtained from chemical analysis and in vitro gas production using rumen fluid. Anim. Res. Dev. 28: 7-55.

Moreau RA, Whitaker BD and Hicks KB (2002). Phytosterols, phytostanols, and their conjugates in foods: structural diversity, quantitative analysis, and health-promoting uses. Prog. Lipid Res. 41: 457-500.

National Research Council (1989). Nutrient Requirements of Dairy Cattle. 6th Rev. Ed. Natl. Acad. Sci., Washington.

Phillipson AT and McAnally RA (1942). Studies on the fate of carbohydrate in the rumen of sheep. J. Exptl. Biol. 19: 199-214.

Searle PL (1984). The berthelot or indophenol reaction and its use in the analytical chemistry of nitrogen. a review. Analyst 109: 549-568.

Trautwein EA, Duchateau GSMJE, Lin Y, Mel'nikov SM, et al. (2003). Proposed mechanisms of cholesterol-lowering action of plant sterols. Eur. J. Lipid Sci. Technol. 105: 171-185.

Van Soest PJ (1982). Nutritional Ecology of the Ruminant. Comstock, Cornell Univ. Press, New York.

Wilt TJ, MacDonald R and Ishani A (1999). Beta-sitosterol for the treatment of benign prostatic hyperplasia: a systematic review. BJU. Int. 83: 976-983. 